\title{
Effect of Plant Extracts on Larval Growth Parameters of Eri Silkworm, Samia ricini Boisd
}

\author{
C. Lalmuankimi*, Inee Gogoi and Th. Aruna Singha \\ Department of Sericulture, Assam Agricultural University, Jorhat, Assam, India \\ *Corresponding author
}

\section{A B S T R A C T}

\section{Keywords}

Eri silkworm,

Samia ricini,

Larval growth

Article Info

\section{Accepted:}

18 November 2020

Available Online:

10 December 2020
The investigation was carried out in the laboratory of Department of Sericulture, Assam Agricultural University, Jorhat. The experiments were laid out in Completely Randomised Design for various estimation of larval parameters of eri silkworm where each treatment and control was replicated three times. From the investigation, it was found that plant extracts have effect on mature larval weight, ERR and larval mortality and moderate concentrations can be adopted for better performance of larval growth.

\section{Introduction}

Sericulture is an agro based popular cottage industry. It involves rearing of silkworms for the production of raw silk, which is the yarn obtained out of cocoons spun by certain species of insects. The major activities of sericulture comprises of food-plant cultivation to feed the silkworms which spin silk cocoons and reeling the cocoons for unwinding the silk filament for value added benefits such as processing and weaving.

Sericulture is broadly divided into two sectors, Mulberry and Non-mulberry. Mulberry sericulture is concerned with mulberry silk production and non-mulberry sericulture includes Eri, Tasar and Muga silk production. The non-mulberry silk are now being popularised as "Vanya silk" (Ahmed and Rajan, 2011).

Eri silkworm can be reared throughout the year to a maximum of 6-7 times a year (Rajesh and Elangovan, 2012). It is domesticated and reared indoor condition. The worms moult four times in 30-35days from hatching to mature cocoon formation stages (Gogoi and Kalita 2009). Eri silkworm is polyphagous species and reared mostly on the leaves of Castor (Ricinus communis L.) and Kesseru (Heteropanax fragrans Seem) plant.

It has been established that the silkworm requires certain essential nutrients such as 
sugars, proteins, amino acids, fatty acids and vitamins for the growth of the silk gland and higher production of silk quality. The silkworm derives almost all the nutrients required for its growth from the host plant leaf.

\section{Materials and Methods}

The investigation on the effect of plant extracts on larval growth parameters of eri silkworm, Samia ricini Boisd. was conducted in the Department of Sericulture, College of Agriculture, Assam Agricultural University, Jorhat during 2015-2017. The host plant treated was Castor, Ricinus communis. Three different plant materials viz. Mikania micrantha, Murraya koenigii and Pongamia glabra for aqueous extraction were utilized.

\section{Preparation of aqueous plant extract}

The plant materials i.e the leaves were washed thoroughly with distilled water to remove the surface contaminants. Then, the plant materials were air dried at room temperature for 5 minutes. Later, the leaves of the plants were taken in mortar and pestle and the aqueous extract were prepared by grinding $100 \mathrm{~g}$ of clean and washed plant material (leaves) in $100 \mathrm{ml}$ of distilled water and then filtered through Whatman filter paper. The filtrates were used as stock solutions and kept in refrigerator. The aqueous extracts of leaves from each plants were then prepared into different concentrations in distilled water viz., 5 per cent, 10 per cent and 15 per cent.

\section{Method of treatment}

The eri silkworm, Samia ricini Boisd. were fed four times in a day with untreated castor leaves upto second instar by maintaining 50 larvae per treatment. The plant extracts were applied to the silkworm host plant i.e. castor leaves by leaf dip method as suggested by
Narayanama et al., (2012). The leaves were dipped in the botanical solutions at different concentrations $(5,10$ and 15 per cent) for 5 minutes, then the solutions were drained out and the dipped castor leaves were air dried at room temperature for five minutes and fed to eri worms four times per day from third instar onwards during rearing period.

\section{Results and Discussion}

\section{Effect of different plant extracts on larval duration of eri silkworm}

It was found that feeding of fortified castor leaves with plant extracts in different concentrations had no significant difference on larval duration of eri silkworm over control (Table 1). The control batch showed the shortest larval duration (21.67 days) and the longest larval duration (24.00 days) was recorded in 15 per cent Murraya koeniigii treated batch. However, the shortest larval duration (22.56 days) was observed in eri silkworm treated with Pongamia glabra leaf extract and the longest larval duration (23.44 days) was recorded on the batch treated with Murraya koeniigi leaf extract. Similar result was also reported by Borah (2004) where the larval duration of eri silkworm fed on castor leaves enriched with soybean and blackgram flour increased over control. Among the concentrations, the shortest larval duration (22.56 days) was found in 5 per cent concentration and the highest was recorded with 15 per cent (23.44 days). The larval duration increased with increase in the concentration (Table 1).

\section{Effect of plant extracts on full grown larval weight of eri silkworm}

The treatments as a whole did not vary significantly when compared with control. However, full grown larval weight was recorded highest $(7.75 \mathrm{~g})$ in 10 per cent 
Mikania micrantha treated eri silkworms and the lowest full grown weight $(7.18 \mathrm{~g})$ in the control batch. It was recorded significantly highest $(7.63 \mathrm{~g})$ on eri silkworms fed with Mikania micrantha treated castor leaves and the lowest full grown larval weight was recorded on Pongamia glabra (7.23 g) which was found at par with Murraya koeniigi treatment $(7.49 \mathrm{~g})$.

Table.1 Effect of plant extracts on Larval duration (days) of eri silkworm

\begin{tabular}{|c|c|c|c|c|}
\hline \multicolumn{4}{|c|}{ Treatment } & \multirow[t]{3}{*}{ Mean } \\
\hline & \multicolumn{3}{|c|}{ Plant extracts } & \\
\hline $\begin{array}{c}\text { Concentration } \\
(\%)\end{array}$ & $\begin{array}{c}\text { Mikania } \\
\text { micrantha }\end{array}$ & $\begin{array}{r}\text { Murraya } \\
\text { koeniigi }\end{array}$ & Pongamia glabra & \\
\hline 5 & 22.67 & 23 & 22 & 22.56 \\
\hline 10 & 22.67 & 23.33 & 22.67 & 22.89 \\
\hline 15 & 23.33 & 24 & 23 & 23.44 \\
\hline Mean & 22.89 & 23.44 & 22.56 & \\
\hline
\end{tabular}

Control: Without treatment - 21.67

Control vs Other treatment- NS

Table.2 Effect of plant extracts on Full grown larval weight (g) of eri silkworm

\begin{tabular}{|c|c|c|c|c|}
\hline \multicolumn{4}{|c|}{ Treatment } & \multirow{2}{*}{ Mean } \\
\cline { 1 - 3 } \begin{tabular}{c|c|c|} 
Plant extracts \\
Concentration
\end{tabular} & $\begin{array}{c}\text { Mikania } \\
\text { micrantha }\end{array}$ & $\begin{array}{c}\text { Murraya } \\
\text { koeniigi }\end{array}$ & Pongamia glabra & \\
\hline $\mathbf{5}$ & 7.63 & 7.46 & 7.21 & 7.44 \\
\hline $\mathbf{1 0}$ & 7.75 & 7.57 & 7.28 & 7.53 \\
\hline $\mathbf{1 5}$ & 7.52 & 7.43 & 7.20 & 7.38 \\
\hline Mean & 7.63 & 7.49 & 7.23 & \\
\hline
\end{tabular}

Control: Without treatment -7.18

Control vs Other treatment- NS

Table.3 Effect of plant extracts on Mature larval weight (g) of eri ilkworm

\begin{tabular}{|c|c|c|c|c|}
\hline \multicolumn{4}{|c|}{ Treatment } & \multirow{2}{*}{ Mean } \\
\hline \begin{tabular}{c|c|c|}
\hline Poncentration \\
$(\mathbf{\%})$
\end{tabular} & $\begin{array}{c}\text { Mikania } \\
\text { micrantha }\end{array}$ & $\begin{array}{c}\text { Murraya } \\
\text { koeniigi }\end{array}$ & Pongamia glabra & \\
\hline $\mathbf{5}$ & 4.65 & 4.55 & 4.42 & 4.54 \\
\hline $\mathbf{1 0}$ & 4.69 & 4.59 & 4.43 & 4.57 \\
\hline $\mathbf{1 5}$ & 4.43 & 4.45 & 4.41 & 4.50 \\
\hline Mean & 4.66 & 4.53 & 4.42 & \\
\hline
\end{tabular}

Control: Without treatment -4.31

Control vs Other treatment: $\mathrm{SEd}( \pm)=0.09, \mathrm{CD}_{0 .}=0.18$ 
Table.4 Effect of plant extracts on Silk gland weight (g) of eri silkworm

\begin{tabular}{|c|c|c|c|c|}
\hline \multicolumn{4}{|c|}{ Treatment } & \multirow{2}{*}{ Mean } \\
\cline { 1 - 3 } $\begin{array}{c}\text { Concentration } \\
(\mathbf{\%})\end{array}$ & $\begin{array}{c}\text { Mikania } \\
\text { micrantha }\end{array}$ & $\begin{array}{c}\text { Murraya } \\
\text { koeniigi }\end{array}$ & Pongamia glabra & \\
\hline $\mathbf{5}$ & 1.92 & 1.87 & 1.82 & 1.87 \\
\hline $\mathbf{1 0}$ & 1.94 & 1.92 & 1.83 & 1.90 \\
\hline $\mathbf{1 5}$ & 1.85 & 1.86 & 1.77 & 1.83 \\
\hline Mean & 1.90 & 1.88 & 1.81 & \\
\hline
\end{tabular}

Control: Without treatment -1.71

Control vs Other treatments: $\operatorname{SEd}( \pm)=0.06, \mathrm{CD}_{0}=0.12$

Table.5 Effect of plant extracts on SGTSI(\%) of eri silkworm

\begin{tabular}{|c|c|c|c|c|}
\hline \multicolumn{4}{|c|}{ Treatment } & \multirow{2}{*}{ Mean } \\
\hline $\begin{array}{c}\text { Concentration } \\
(\%)\end{array}$ & $\begin{array}{c}\text { Mikania } \\
\text { micrantha }\end{array}$ & $\begin{array}{c}\text { Murraya } \\
\text { koeniigi }\end{array}$ & Pongamia glabra & \\
\hline $\mathbf{5}$ & 43.97 & 41.12 & 40.14 & 41.74 \\
\hline $\mathbf{1 0}$ & 44.67 & 41.73 & 41.94 & 42.78 \\
\hline $\mathbf{1 5}$ & 43.39 & 41.02 & 40.04 & 41.48 \\
\hline Mean & 44.01 & 41.29 & 40.71 & \\
\hline
\end{tabular}

Control: Without treatment -39.61

Control vs Other treatments: NS

Table.6 Effect of plant extracts on ERR(\%) of eri silkworm

\begin{tabular}{|c|c|c|c|c|}
\hline \multicolumn{4}{|c|}{ Treatment } & \multirow{2}{*}{ Mean } \\
\cline { 1 - 3 } $\begin{array}{c}\text { Concentration } \\
(\mathbf{\%})\end{array}$ & $\begin{array}{c}\text { Mikania } \\
\text { micrantha }\end{array}$ & $\begin{array}{c}\text { Murraya } \\
\text { koeniigi }\end{array}$ & Pongamia glabra & \\
\hline $\mathbf{5}$ & 86.33 & 90.00 & 77.00 & 84.44 \\
\hline $\mathbf{1 0}$ & 86.67 & 91.33 & 76.67 & 84.88 \\
\hline $\mathbf{1 5}$ & 86.00 & 88.33 & 76.33 & 83.56 \\
\hline Mean & 86.33 & 89.89 & 76.67 & \\
\hline
\end{tabular}

Control: Without treatment -78.00

Control vs Other treatments: $\mathrm{SEd}( \pm)=1.86, \mathrm{CD}_{0}=3.87$ 
Table.7 Effect of plant extracts on Larval mortality (\%) of eri silkworm

\begin{tabular}{|c|c|c|c|c|}
\hline \multicolumn{4}{|c|}{ Treatment } & \multirow{2}{*}{ Mean } \\
\cline { 1 - 3 } $\begin{array}{c}\text { Concentration } \\
(\mathbf{\%})\end{array}$ & $\begin{array}{c}\text { Mikania } \\
\text { micrantha }\end{array}$ & $\begin{array}{c}\text { Murraya } \\
\text { koeniigi }\end{array}$ & Pongamia glabra & \\
\hline $\mathbf{5}$ & 13.67 & 10.00 & 23 & 15.56 \\
\hline $\mathbf{1 0}$ & 13.33 & 08.67 & 23.33 & 15.11 \\
\hline $\mathbf{1 5}$ & 14.00 & 11.67 & 23.67 & 16.44 \\
\hline Mean & 13.67 & 10.11 & 23.33 & \\
\hline
\end{tabular}

Control: Without treatment - 22.67

Control vs Other treatments: $\operatorname{SEd}( \pm)=1.91, \mathrm{CD}_{0 .}=3.98$

The concentrations of all plant extracts showed the difference in full grown larval weight but the difference in weight among the concentrations were not statistically significant. However, 10 percent showed highest full grown larval weight $(7.53 \mathrm{~g})$ followed by 5 per cent $(7.44 \mathrm{~g})$ and 15 per cent $(7.38 \mathrm{~g})$. Similar results was also reported by Deshmukh and Khyade (2012) where they observed the increased weight of final instar larvae of Bombyx mori upon receiving supplementation of Aloe tonic.

\section{Effect of plant extracts on mature larval weight of eri silkworm}

The fortified castor leaves with plant extracts significantly increase the weight of mature larva of eri silkworm over the control batches of worms (Table 3). The treatment of 10 per cent Mikania micrantha showed the highest mature larval weight $(4.69 \mathrm{~g})$, followed by 5 per cent Mikania micrantha extracts (4.65 g) and the lowest mature larval weight was in control (4.31 g). The plant extracts irrespective of concentrations were found to have significant effect on mature larval weight of eri silkworm (Table 3). The leaf extracts of Mikania micrantha exhibited highest mature larval weight $(4.66 \mathrm{~g})$ and found to be at par with Murraya koeniigi leaf extracts $(4.53 \mathrm{~g})$ while the lowest mature larval weight was in Pongamia glabra treated batch (4.42g). 10 per cent concentration showed highest larval weight $(4.57 \mathrm{~g})$ followed by 5 per cent $(4.54 \mathrm{~g})$ and 15 per cent (4.50 g). Pardeshi and Bajad (2014) also observed the increase in larval weight in third, fourth and fifth instar larvae on diet supplementation of Amaranthus hybridus plant extracts to the silkworm.

\section{Effect of plant extracts on silk gland weight of eri silkworm}

All the treatments when compared with control showed statistically significant effect on silk gland weight of eri silkworm (Table 4). Mikania micrantha at 10 per cent (1.94 g) revealed the highest silk gland weight and this was found at par with 5 per cent Mikania micrantha $(1.92 \mathrm{~g})$ and 10 per cent Murraya koeniigi $(1.92 \mathrm{~g})$. The lowest silk gland weight was observed in the untreated castor leaves $(1.71 \mathrm{~g})$. The highest silk gland weight was exhibited in Mikania micrantha treated batch $(1.90 \mathrm{~g})$ and the lowest silk gland weight in Pongamia glabra treated batch $(1.81 \mathrm{~g})$. Among the concentrations, 10 per cent revealed the highest silk gland weight $(1.90 \mathrm{~g})$ followed by 5 per cent $(1.87 \mathrm{~g})$ and 15 per cent $(1.83 \mathrm{~g})$. These findings uphold the observation recorded earlier by Devi (2013) where the eri silkworm reared on castor leaves fortified with Mikania micrantha leaf extracts recorded increased 
silk gland protein concentration of fifth instar larvae over control.

\section{Effect of plant extract on Silk gland tissue somatic index of eri silkworm}

The study indicated that the treatments as a whole did not show statistically significant increase on silk gland tissue somatic index (SGTSI) over control (Table 5). All the treatments however showed comparatively higher SG TSI than control (39.61\%). The botanicals had significant effect on silk gland tissue somatic index of eri silkworm (Table 5).

Among the plant extracts significantly highest silk gland tissue somatic index $(44.01 \%)$ was recorded on eri silkworm fed on Mikania micrantha treated castor leaves and the lowest on Pongamia glabra (40.71\%) and found to be at par with Murraya koeniigi (41.29\%). The highest SGTSI (42.78\%) was registered in 10 per cent and lowest $(41.48 \%)$ was observed in 15 per cent.

\section{Effect of plant extracts on effective rate of rearing of eri silkworm}

The fortified castor leaves as a whole had significant difference on effective rate of rearing (ERR) over untreated batch (Table 6). The highest effective rate of rearing $(91.33 \%)$ was registered when larvae fed on castor leaves fortified with 10 per cent Murraya koeniigi leaf extracts, followed by 5 per cent Murraya koeniigi extracts while the lowest ERR (76.33 \%) was in 15 per cent Pongamia glabra extracts. The plant extracts were found to have significant effect on effective rate of rearing of eri silkworm (Table 6). Murraya koeniigi extracts showed significantly highest effective rate of rearing $(89.89 \%)$ among the plant extracts while the lowest ERR was in Pongamia glabra extracts (76.67 \%). This finding is in accordance with Narayanamma et al., (2012) and Mortale et al., (2013) where Pongamia oil was found to have adverse effect on effective rate of rearing and larval mortality when compared over control.

\section{Effect of plant extracts on larval mortality of eri silkworm}

Feeding of fortified castor leaves with different plant extracts with different concentrations had significant difference on larval mortality compared to control (Table 7). Murraya koeniigi extracts at 10 per cent exhibited lowest larval mortality $(8.67 \%)$ which was at par with Muraya koeniigi at 5 per cent $(10.00 \%)$ while the highest larval mortality (23.67\%) in 15 per cent Pongamia glabra extracts treated batch.

The effects of plant extracts on larval mortality were found to be significant (Table $7)$. The lowest significant mortality $(10.11 \%)$ was noted on Murraya koeniigi leaf extracts and the highest mortality $(23.33 \%)$ was observed on Pongamia glabra leaf extracts. This finding is in accordance with Narayanamma et al., (2012) and Mortale et al., (2013) where Pongamia oil was found to have adverse effect on effective rate of rearing and larval mortality when compared over control. Ten per cent of all the plant extracts exhibited lowest larval mortality $(15.11 \%)$.

In conclusion, all the plant extracts showed some effect on the studied larval parameters of eri silkworm. Effect of plant extracts as a whole when compared over control showed significant result in mature larval weight, effective rate of rearing, larval mortality, silk gland weight. The other parameters viz., larval duration, full grown larval weight, silk gland tissue somatic index were found to be nonsignificant. Among the concentrations 10 percent exhibited better results in all the parameters. 


\section{References}

Ahmed, S.A. and Rajan, R.K. (2011). Exploration of vanya silk biodiversity in North Eastern Region of India: Sustainable livelihood and poverty alleviation. Proceedings of International Conference on Management, Economics and Social Sciences (ICMESS'2011), December 23-24, 2011 at Bangkok, Thailand, pp. 485489.

Bohidar, K., and Manita Chaubey., (2005). Effect of some indigenous plant extracts on the economic characters of Mulberry silkworm Bombyx mori. Indian J. of Entomol. 67 (3): 238-240.

Desmukh,B.R and Khyade,B.V (2012) Utilisation of Aloe vera L. herbal tonic for treating mulberry leaves before feeding the fifth instar larvae of silkworm, Bombyx mori L. Inter. J. Bioassays ISSN:2278-778X.

Devi, M. (2013). Study on the impact of Mikania micrantha leaf extract feeding on Silk gland protein concentration of V instar Eri silkworm Samia ricini Donovan. The Clarion 2(2):17-20.
Gogoi, N and Kalita, B.B (2009) Eri silk- Its properties and processing. pp-17.

Mortale, H.T.; Narayanaswamy, T.K.; Biradar, J.; Chikkalingaiah and Babu, S.H. (2013). Impact of botanicals on the growth and silk production of Eri silkworm, Samia cynthia ricini (Boisduval). Curr. Biotica 7(3): 233235.

Narayanamma, V.L.; Reddy, K.D. and Reddy, A.V. (2012). Effect of botanical insecticides on the growth and silk production of Ambagoan and Lakhimpur strains of eri silkworm, Samia cynthia ricini (Boidsduval). $J$. Biopest. 6(1): 41-45.

Pardeshi, A.B. and Bajad, P.N. (2014). The effect of nutritional supplementation with Amaranthus hybridus Linn. extract on economic performance of Mulberry silkworm, Bombyx mori L. Sch. Acad. J. Biosci. 2(4): 272-276.

Rajesh Kumar and Elangovan, V. (2012). Rearing performance of different ecoraces of eri silkworm (Philosamia ricini) Donovan during Summer season of Uttar Pradesh. J. Expt. Zool. 15(1): 163-168.

\section{How to cite this article:}

Lalmuankimi, C., Inee Gogoi and Aruna Singha, Th. 2020. Effect of Plant Extracts on Larval Growth Parameters of Eri Silkworm, Samia ricini Boisd. Int.J.Curr.Microbiol.App.Sci. 9(12): 2655-2661. doi: https://doi.org/10.20546/ijcmas.2020.912.314 